\title{
Annual Report on the External Quality Assessment Scheme for Transfusion Medicine in Korea (2017)
}

Young Ae $\operatorname{Lim}^{1,2}$ and Hyun Soo $\mathrm{Cho}^{2}$

${ }^{1}$ Department of Laboratory Medicine, Ajou University School of Medicine;

${ }^{2}$ Department of Laboratory Medicine, Ajou University Hospital, Suwon, Korea

Corresponding author: Young Ae Lim

Department of Laboratory Medicine, Ajou University Hospital, Ajou University School of Medicine, 164 World cup-ro, Yeongtong-gu, Suwon 16499, Korea

Tel: $+82-31-219-5786$

Fax: $+82-31-219-5778$

E-mail: limyoung@ajou.ac.kr
Here, we have reported results of the surveys on the external quality assessment scheme (EQA) of the Transfusion Medicine Program (TMP) in Korea that were carried out in 2017. The proficiency testing specimens were prepared at Ajou University Hospital, and sent to the participants biannually. The average accuracy rates ( $\mathrm{N}=$ the number of participants) for ten different test items on the regular survey were as follows: ABO typing, $99.1 \%-99.9 \%$ ( $\mathrm{N}=714)$; RhD typing, 99.3\%-100.0\% ( $\mathrm{N}=695)$; crossmatching, $88.9 \%-98.5 \%(\mathrm{~N}=618)$; ABO subtyping, $80.7 \%$ and $96.0 \%(\mathrm{~N}=51)$; Rh CcEe antigen testing, $98.8 \%-100.0 \%(\mathrm{~N}=51)$; weak D test, $99.3 \%$ and $100.0(\mathrm{~N}=150)$; antibody screening, $98.6 \%-100.0 \%(\mathrm{~N}=295)$; direct antiglobulin test (DAT) using a poly-specific reagent, 99.2\%-100.0 (N=256); DAT using an immunoglobulin-G monospecific reagent, all 100.0\% (N=68); DAT using a C3dmonospecific reagent, $83.6 \%-100.0 \%(\mathrm{~N}=72)$; antibody identification, $88.7 \%-99.2 \%$ $(\mathrm{N}=123)$; and $\mathrm{ABO}$ Ab titration, $84.6 \%-100.0 \%(\mathrm{~N}=73)$. The number of participants for the EQA for TMP in 2017 was much higher than that in 2016. Except for the case of ABO subtyping, excellent survey results for the 2017 EQA for TMP were obtained, compared to those in 2016. Thus, the EQA for TMP in 2017 should be helpful for improving the quality of the participating laboratories.

(J Lab Med Qual Assur 2018;40:9-20)

Key Words: Transfusion medicine, Quality improvement, Laboratory proficiency testing

\section{서론}

수혈 전 검사의 정확성은 환자의 생명과도 관련이 있으므로 정확성이 보증되어야 한다. 대부분 혈액은행에서 실시하고 있 는 검사의 원리는 적혈구와 혈장 혹은 혈청을 이용한 면역혈구 응집법 검사이며 수기법으로 시행하고 있다는 특징이 있다. 이 러한 수기법은 자동화에 비하여 검사결과의 편차가 클 수 있으 며 사무적인 오류 발생가능성도 크다고 볼 수 있다. 이러한 이 유로 혈액은행검사의 외부정도관리 참여는 검사의 신뢰도를 평가할 수 있는 매우 중요한 과정이라고 할 수 있다.

대한임상검사정도관리협회에서 새롭게 사업프로그램을 구 성하고 차세대 전산시스템을 개발하여 차세대 신빙도조사 사업을 시행하게 된 지 올해로 2년이 되었다. 2016년에 이어 2017년부터는 수혈의학검사들이 다음과 같이 4개의 프로그램 으로 나뉘어 10 가지의 항목으로 시행하고 있다[1]. (1) 일반
수혈검사: $\mathrm{ABO}$ typing ( $\mathrm{ABO}$ 혈액형), $\mathrm{RhD}$ typing $(\mathrm{RhD}$ 혈액형), crossmatching(교차시험); (2) 수혈항원검사, 특 수: $\mathrm{ABO}$ subtyping ( $\mathrm{ABO}$ 아형 혈액형), Rh CcEe antigen testing (Rh CcEe 항원검사), weak D test(약 D검사); (3) 수 혈항체검사, 일반: antibody screening(비예기항체 선별검사), direct antiglobulin test(직접항글로불린검사); (4) 수혈항체 검사, 특수: antibody identification(비예기항체 동정검사), $\mathrm{ABO} \mathrm{Ab}$ titration (ABO 항체 역가검사). 이 4개의 수혈의학 프로그램은 2016년과 동일한 수혈의학프로그램 관리자에 의 하여 관리되어 왔다.

이에 저자들은 2017년에 4개의 수혈의학프로그램에서 실시 한 10 가지의 검사항목에 대하여 2차에 걸쳐 신빙도조사를 실 시하였고, 기관별 검사방법에 대한 결과와 실시하였던 사업내 용을 보고하고자 한다. 


\section{재료 및 방법}

\section{1. 조사항목}

조사항목은 서론에서 언급한 바와 마찬가지로 $\mathrm{ABO}$ 혈액형, $\mathrm{RhD}$ 혈액형, 교차시험, $\mathrm{ABO}$ 아형 혈액형, $\mathrm{Rh} \mathrm{CcEe}$ 항원검 사, 약 $\mathrm{D}$ 검사, 비예기항체 선별검사, 직접항글로불린검사, 비 예기항체 동정검사, $\mathrm{ABO}$ 항체 역가검사의 10 가지 항목에 대 한 신빙도조사를 실시하였다.

\section{2. 외부신빙도 조사물질용 제조}

검체 제조는 2016년도와 마찬가지로 2017년 차세대 신빙도 조사사업을 위한 자가제조물질 개발의 용역연구를 맡은 아주 대학교병원에서 다음과 같이 제조하였다. 검체 제조에 사용된 혈액제제들은 대한적십자사와 한마음 혈액원으로부터 생명윤 리심의를 득한 후에 사용하였다. 자가제조된 모든 검체는 객 관적 판독을 위하여 검사자 2 인이 각각 검사하여 결과 및 응집 정도를 확인하였다. 아주대학교병원에서 제조되고 분주 후 표 식이 붙여진 외부신빙도조사물질들은 대한임상검사정도관리 협회로 운반되어 포장된 후 각 참여기관으로 발송되었다. 외부 신빙도조사 검체는 1차 4월 17일, 2차는 9월 18일에 계약 택배 를 이용하여 각각 발송하였다. 검사결과는 차세대 신빙도조사 사업 홈페이지에 입력하도록 하였다.

\section{1) 혈구부유액 제조}

신빙도조사 검사항목(각 회차당 검체 수)인 $\mathrm{ABO}$ 혈액형의 혈구형 검사(3개), $\mathrm{RhD}$ 혈액형(3개), $\mathrm{ABO}$ 아형 혈액형(1개), $\mathrm{Rh} \mathrm{CcEe}$ 항원검사(1개), 그리고 약 $\mathrm{D}$ 검사(1개)를 위한 적혈 구 부유액은 목적하고자 하는 혈액형을 가진 혈액을 혈구보 존액인 $\mathrm{EC}$ stabilizing solution (DiaMed $\mathrm{GmbH}$, Cressier, Switzerland)을 사용하여 희석하였다. ABO 혈액형의 혈구형 검사와 $\mathrm{RhD}$ 혈액형 검사용 혈구부유액은 자동화 장비에도 사 용이 가능하도록 하였다. 이를 위하여 $20 \%$ 의 재조합 전혈이 되도록 신선동결혈장과 EC stabilizing solution으로 희석하였 고, $\mathrm{ABO}$ 아형 혈액형, $\mathrm{Rh} \mathrm{CcEe}$ 항원검사 그리고 약 $\mathrm{D}$ 검사 용 적혈구 부유액은 $3 \%$ 가 되도록 하였다. 교차시험용 적혈구 부유액은 3 개의 $\mathrm{ABO}$ 혈액형의 혈구형 검사용 검체 중 하나 를 사용하도록 하였다. $\mathrm{ABO}$ 아형 혈액형과 약 $\mathrm{D}$ 검사 검체는 동일한 혈액형을 가진 EDTA (ethylenediamine tetraacetic acid) 유래검사용 검체들을 각각 혼주하여 사용하였고, 그 이 외는 CPDA (citrate phosphate dextrose adenine)-1 혈액 백 에서 분리된 농축적혈구를 사용하였다 [1,2]. 동일한 $\mathrm{ABO}$ 혈 액형의 혈액백의 혼주 시는 무균봉합기로 연결하여 혼합한 다
음 분주하였다.

\section{2) 혈장용 검체 제조}

$\mathrm{ABO}$ 혈청 검사용은 혈구형과 동일한 $\mathrm{ABO}$ 혈액형, $\mathrm{ABO}$ 항체 역가검사용은 $\mathrm{O}$ 형의 신선동결혈장을 사용하였다. 혈액 백의 혼주 시는 무균봉합기로 연결하여 혼합한 다음 분주하였 다[1,2].

\section{3) 재조합 혈장 검체 제조}

신빙도조사 검사항목(각 회차당 검체 수)인 교차시험(3개), 비예기항체 선별검사(3개), 비예기항체 동정검사(2개)는 항혈 청에 신선동결혈장으로 희석하여 재조합하였다. 교차시험 양 성 검체는 항글로불린 단계에서만 검출되고 그 이외의 단계에 서는 검출되지 않거나 약하게 검출될 정도의 항혈청의 항체 역 가를 희석하여 검체를 제조하였는데, 상품화된 인간유래 다클 론성 anti-D (DiaMed $\mathrm{GmbH}$ )를 동일한 $\mathrm{ABO}$ 혈액형의 신선 동결혈장에 희석하여 사용하였다[1,2].

비예기항체 선별검사용 양성 검체로는 1 회차 anti-K, anti-E 를, 2 회차 anti-e를 발송하였고, 동정용 양성 검체로는 1 회차 anti-Fy ${ }^{\mathrm{a}}$, anti-N를, 2회차 anti-K, anti-e를 발송하였다. 검 체는 항혈청 시약을 각각 희석하여 사용하였는데 사용된 항혈 청 시약의 종류는 각각 다클론성 anti-Fy ${ }^{\mathrm{a}}$ (CE Diagnostika $\mathrm{GmbH}$, Eschelbronn, Germany), 단클론성 anti-N (CE Diagnostika $\mathrm{GmbH}$ ), 다클론성 anti-K (CE Diagnostika $\mathrm{GmbH}$ ), 단클론성 anti-e (Diagast, Parc Eurasanté, France)였다. 희 석 시는 $\mathrm{AB}$ 혈액형의 신선동결혈장에 희석하였다 $[1,2]$.

\section{4) 직접항글로불린검사용 혈구 제조}

양성 직접항글로불린검사용 검체는 인간유래 다클론성 anti-D (DiaMed GmbH)를 사용하여 인위적으로 감작시킨 혈구를 사용하였다. 음성 직접항글로불린검사용 혈구는 직접 항글로불린 검사결과 음성인 적혈구를 사용하였다. 양성 및 음 성 혈구들은 혈구보존액인 EC stabilizing solution (DiaMed $\mathrm{GmbH}$ )에 $3 \%$ 로 희석하여 이용하였다.

\section{3. 결과 판정 및 분석 검체}

일반수혈검사의 $\mathrm{ABO}$ 혈액형, $\mathrm{RhD}$ 혈액형과 교차시험의 경우 혈구응집 강도에 대하여 의도한 범위는 보고서에 제공하 였으나 이들은 모두 code 507로 시범항목으로 간주하여 평가 에서 제외하였다. 또한 $\mathrm{ABO}$ typing 검사에서 혈구형이나 혈 청만을 실시하거나 특수 혈액형항원검사에서 응집 강도만 표 시하고 항원형 판정을 하지 않은 기관에 대해서는 시범항목으 


\section{Journal of LABORATORY MEDICINE and QUALITY ASSURANCE}

Young Ae Lim et al • Annual Report (2017) for Transfusion Medicine EQA

로 간주하여 평가하지 않았다. 교차시험이나 해당 검사를 시행 하기에 적절하지 않은 slide법은 분석에서 제외하였다. 교차시 험의 경우 음성으로 적합 판정을 한 검체에 대해서는 응집이 없다고 보고한 경우만 정답으로 간주하였다. $\mathrm{Rh} \mathrm{CcEe}$ 항원검 사와 직접항글로불린검사의 경우 $1+$ 이상을 양성으로 간주 하여 양성 검체의 정답률을 산정하였다. $\mathrm{ABO}$ 항체 역가검사 의 허용범위는 참여기관이 10 기관 이상인 검사법에 대하여 최 빈도와 상하 단계씩 추가하였고, 이 범위에 속하는 참여기관이 $80 \%$ 를 넘지 않을 경우에는 최빈도와 상하 단계 근처의 빈도 수가 많은 단계를 더 추가하여 결정하였다.

\section{결과}

\section{1. 일반수혈검사}

\section{1) $\mathrm{ABO}$ 와 $\mathrm{RhD}$ 혈액형}

$\mathrm{ABO}$ 혈액형검사는 2 차에 걸쳐 총 6 개의 검체로 실시하였 고, 정답률은 99.1\%-99.9\%를 나타냈다(Table 1). 1차(2차) 의 혈구형 검사법은 슬라이드법 $48.9 \%$ (52.0\%), 시험관법 $43.3 \%$ (40.3\%) 순이었으며, 1차(2차)의 혈청형 검사법은 시 험관법이 $85.7 \%$ (84.6\%), 슬라이드법 $7.4 \%$ (8.7\%) 순으로 나타났다. $\mathrm{RhD}$ 혈액형검사도 2 차에 걸쳐 총 6 개의 검체로 실
시하였고, 정답률은 99.3\%-100.0\%를 나타내어 작년도에 비 하여 정답률이 소폭 증가하였다(Table 2). 1차(2차)의 검사법 은 1차에서는 시험관법이 $51.5 \%$ (48.7\%), 슬라이드법 $40.2 \%$ (43.7\%) 순이었다.

\section{2) 교차시험}

교차시험검사는 2 차에 걸쳐 총 6 개의 검체가 사용되었으며, 적합 검체는 $97.6 \%-98.5 \%$, 부적합 검체는 $88.9 \%$ 와 $90.4 \%$ 의 교차시험 판정 정답률을 보여 $95.3 \%$ 의 평균 정답률을 보였 다(Table 3). 부적합 검체의 경우 각 방법별로 분석한 결과, 시 험관법의 식염수단계와 $37^{\circ} \mathrm{C}$ 알부민단계에서는 대부분의 기 관에서 음성으로 보고한 반면, 시험관법의 $37^{\circ} \mathrm{C}$ 알부민단계는 trace에서 $2+$ 의 범위를 나타내기도 하였으며, 대부분의 시험 관법 항글로불린단계와 원주응집법은 $1+$ 이상의 응집을 나타 내었다(Fig. 1).

\section{2. 특수 수혈항원검사}

\section{1) $\mathrm{ABO}$ 아형 혈액형}

1 차 검체는 $\mathrm{A}_{2}$ 형으로 $96.0 \%$ (48/50)의 정답률을 보였는 데 항- $\mathrm{A}_{1}$ 시약과의 반응에서 음성 혹은 trace를 보인 기관은 $96.0 \%$, 항-H 시약과의 반응에서 $1+$ 이상을 보고한 기관은

Table 1. Number (\%) of participants in the proficiency tests for ABO blood grouping in 2017

\begin{tabular}{ccccccccc}
\hline Trial & Specimen & Total & A & B & O & Dis & NA & Intended response \\
\hline 1 & BB-17-01 & $669(100.0)$ & $668(99.9)$ & $1(0.1)$ & - & - & - & A \\
& BB-17-02 & $669(100.0)$ & - & $2(0.3)$ & $663(99.1)$ & $4(0.6)$ & - & O \\
& BB-17-03 & $669(100.0)$ & $1(0.1)$ & $664(99.3)$ & $3(0.5)$ & $1(0.1)$ & - & B \\
2 & BB-17-07 & $759(100.0)$ & $1(0.1)$ & $755(99.5)$ & - & $3(0.4)$ & - & B \\
& BB-17-08 & $759(100.0)$ & $755(99.5)$ & $1(0.1)$ & - & $3(0.4)$ & - & A \\
& BB-17-09 & $759(100.0)$ & - & - & $755(99.5)$ & $4(0.5)$ & - & O \\
\hline
\end{tabular}

Values are presented as number (\%), unless otherwise stated.

Abbreviations: Dis, discrepancy between cell typing and serum typing; NA, not available.

Table 2. Number (\%) of participants in the proficiency tests for RhD typing in 2017

\begin{tabular}{|c|c|c|c|c|c|c|c|}
\hline Trial & Specimen & Total & Positive & Variant & Negative & NA & Intended response \\
\hline \multirow[t]{3}{*}{1} & BB-17-01 & $650(100.0)$ & 649 (99.8) & $1(0.2)$ & - & - & Positive \\
\hline & BB-17-02 & $650(100.0)$ & $650(100.0)$ & - & - & - & Positive \\
\hline & BB-17-03 & $650(100.0)$ & $1(0.2)$ & - & 649 (99.8) & - & Negative \\
\hline \multirow[t]{3}{*}{2} & BB-17-07 & $740(100.0)$ & $740(100.0)$ & - & - & - & Positive \\
\hline & BB-17-08 & $740(100.0)$ & 739 (99.9) & $1(0.1)$ & - & - & Positive \\
\hline & BB-17-09 & $740(100.0)$ & $3(0.4)$ & $2(0.3)$ & $735(99.3)$ & - & Negative \\
\hline
\end{tabular}

Values are presented as number (\%), unless otherwise stated.

Abbreviation: NA, not available. 
Journal of LABORATORY MEDICINE and QUALITY ASSURANCE

Young Ae Lim et al • Annual Report (2017) for Transfusion Medicine EQA

Table 3. Number and \% of participants in the proficiency tests for blood crossmatching

\begin{tabular}{|c|c|c|c|c|}
\hline Trial (RBC) & Specimen & Intended response & Results & No. (\%) \\
\hline \multirow[t]{6}{*}{ 1st (BB-17-02) } & BB-17-04 & Incompatible & Acceptable & $518(88.9)$ \\
\hline & & & Unacceptable & $65(11.1)$ \\
\hline & BB-17-05 & Compatible & Acceptable & $574(98.5)$ \\
\hline & & & Unacceptable & $9(1.5)$ \\
\hline & BB-17-06 & Compatible & Acceptable & $568(97.6)$ \\
\hline & & & Unacceptable & $14(2.4)$ \\
\hline \multirow[t]{6}{*}{ 2nd (BB-17-08) } & BB-17-10 & Compatible & Acceptable & $642(98.3)$ \\
\hline & & & Unacceptable & $11(1.7)$ \\
\hline & BB-17-11 & Compatible & Acceptable & $642(98.3)$ \\
\hline & & & Unacceptable & $11(1.7)$ \\
\hline & BB-17-12 & Incompatible & Acceptable & $591(90.4)$ \\
\hline & & & Unacceptable & $63(9.6)$ \\
\hline
\end{tabular}

Abbreviation: RBC, sample codes for red blood cell suspensions.
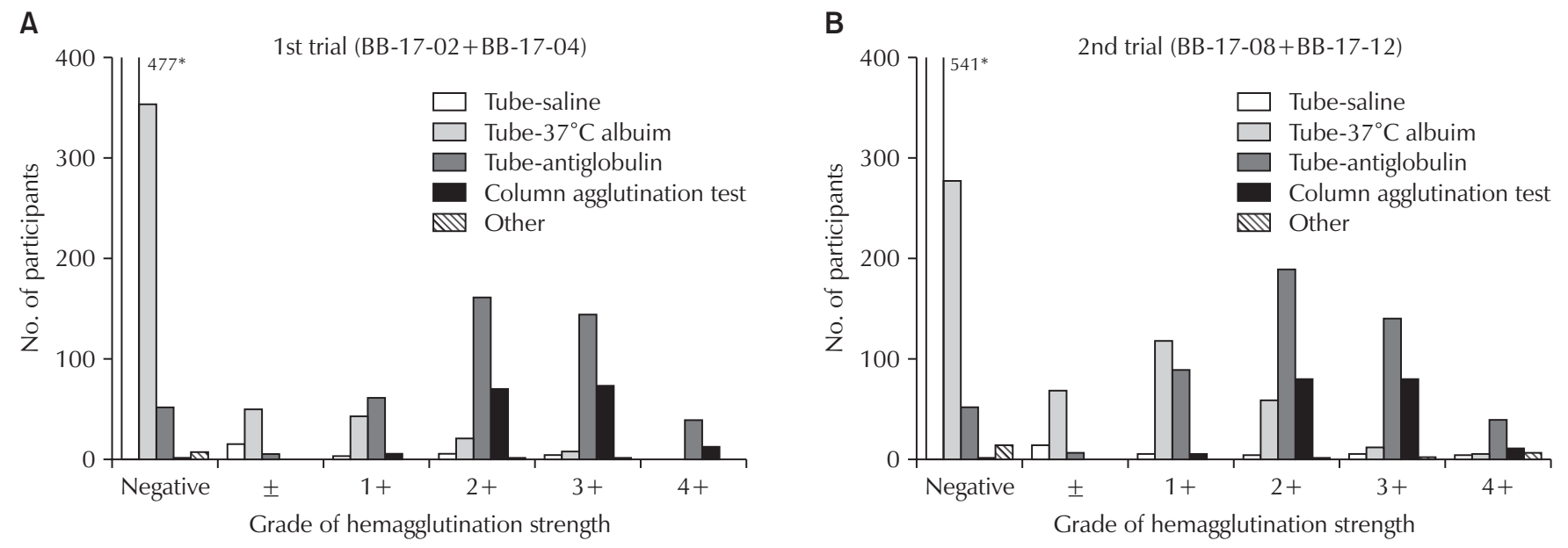

Fig. 1. (A, B) A graph showing the number of participants (Y-axis) versus the grade of hemagglutination strength (X-axis) of incompatible samples for blood crossmatching. ${ }^{*}$ The number of participants using tube-saline.

$89.7 \%$ 였다. 2 차 검체는 $\mathrm{A}_{2} \mathrm{Bw}$ 형으로 $80.7 \%$ (42/50)의 정답 률에 지나지 않았다. 항-B 시약과의 반응에서 혼합시약을 포 함하여 trace부터 $3+$ 까지의 응집을 보고한 기관은 $92.3 \%$ 였 으며 $\mathrm{B}$ 아형을 검출한 기관은 $84.6 \%$ 였다. 항-H 시약과의 반 응에서 한 개의 기관을 제외하고는 모든 기관에서 $1+$ 이상을 보고하여 97.9\%였다(Table 4).

\section{2) Rh CcEe 항원검사}

$\mathrm{Rh} \mathrm{CcEe}$ 항원검사는 1 차 50 개, 2 차 51 개 기관에서 참여하 였다. 1 차 검체는 $\mathrm{CcEe}, 2$ 차 검체 Cce 검체를 발송하였는데 2 차 검체에서 $\mathrm{E}$ 항원에 양성, $\mathrm{c}$ 항원에 음성이라 각각 응답한 두 개의 기관들을 제외한 나머지 기관과 1 차의 모든 기관에서는
정답으로 답변하였다(Table 5).

3) 약 $D$ 검사

2017년에 보낸 약 D검사는 모두 RhD typing에서도 응집 을 보였던 변이형 $\mathrm{D}$ 형 검체였으나, 1 차 $51.7 \%$ (74/143), 2 차 는 78.7\% (126/160)에서만 의도한 변이형 D로 보고하였다. 그러나 1 차와 2 차 검체 모두 참여기관의 상당수에서 D 양성으 로 보고하여 올해에 한하여 정답으로 간주하여 정답률은 1 차 $99.3 \%, 2$ 차는 $100.0 \%$ 에 달하였다. $\mathrm{RhD}$ 혈액형검사에서 $4+$ 응집을 보여 부적격으로 판정된 기관은 1 차 2 기관, 2 차는 1 기 관이었다(Table 6). 


\section{Journal of LABORATORY MEDICINE and QUALITY ASSURANCE}

Young Ae Lim et al • Annual Report (2017) for Transfusion Medicine EQA

Table 4. Number (\%) of participants in the proficiency tests for ABO subtyping

\begin{tabular}{|c|c|c|c|c|c|c|c|}
\hline \multirow{3}{*}{$\begin{array}{l}\text { Trial (specimen) } \\
1 \text { st (BGS-17-01) }\end{array}$} & \multirow{3}{*}{$\begin{array}{l}\text { Category } \\
\text { Number }\end{array}$} & \multicolumn{4}{|c|}{ Anti-sera } & \multirow{2}{*}{\multicolumn{2}{|c|}{ ABO subgroup }} \\
\hline & & \multirow{2}{*}{$\begin{array}{c}\text { Anti-A } \\
50\end{array}$} & \multirow{2}{*}{$\begin{array}{c}\text { Anti-B } \\
50\end{array}$} & \multirow{2}{*}{$\begin{array}{c}\text { Anti-A } \\
50\end{array}$} & \multirow{2}{*}{$\begin{array}{c}\text { Anti-H } \\
39\end{array}$} & & \\
\hline & & & & & & $\mathrm{A}_{1}$ & $1(2.0)^{\star}$ \\
\hline & Negative & - & $50(100.0)$ & $46(92.0)$ & - & $\mathrm{A}_{2}$ & $48(96.0)$ \\
\hline & \pm & - & - & $2(4.0)$ & $4(10.3)^{*}$ & Aw & $1(2.0)^{\star}$ \\
\hline & $1+$ & - & - & - & $13(33.3)$ & & \\
\hline & $2+$ & $1(2.0)^{\star}$ & - & $1(2.0)^{*}$ & $16(41.0)$ & & \\
\hline & $3+$ & $2(4.0)$ & - & - & $6(15.4)$ & & \\
\hline & $4+$ & 47 (94.0) & - & - & - & & \\
\hline & MF & - & - & $1(2.0)^{\star}$ & - & & \\
\hline \multirow[t]{8}{*}{ 2nd (BGS-17-04) } & Number & 52 & 52 & 52 & 48 & $\mathrm{~A}_{2} \mathrm{~B}$ & $7(13.5)^{*}$ \\
\hline & Negative & - & - & $52(100.0)$ & - & $\mathrm{A}_{2} \mathrm{Bw}$ & $42(80.7)$ \\
\hline & \pm & - & $2(3.8)$ & - & $1(2.1)^{\star}$ & AwB & $2(3.9)^{\star}$ \\
\hline & $1+$ & - & $4(7.7)$ & - & $6(12.5)$ & $\mathrm{AwBw}$ & $1(1.9)^{\star}$ \\
\hline & $2+$ & - & $13(25.0)$ & - & $18(37.5)$ & & \\
\hline & $3+$ & $2(3.8)$ & $12(23.1)$ & - & $12(25.0)$ & & \\
\hline & $4+$ & $50(96.2)$ & $4(7.7)^{\star}$ & - & $11(22.9)$ & & \\
\hline & MF & - & $17(32.7)$ & - & - & & \\
\hline
\end{tabular}

Values are presented as number (\%), unless otherwise stated.

Abbreviation: MF, mixed field agglutination.

${ }^{\star}$ Unacceptable responses for $\mathrm{ABO}$ subgrouping.

Table 5. Number (\%) of participants in the proficiency tests for Rh CcEe antigen typing

\begin{tabular}{|c|c|c|c|c|c|}
\hline \multirow{2}{*}{ Trial (specimen) } & \multirow{2}{*}{ Category } & \multicolumn{4}{|c|}{ Anti-sera } \\
\hline & & $\mathrm{C}$ & $\mathrm{E}$ & c & e \\
\hline \multirow[t]{5}{*}{ 1st (BGS-17-02) } & Number & 50 & 50 & 50 & 50 \\
\hline & $1+$ & $2(4.0)$ & - & $1(2.0)$ & $2(4.0)$ \\
\hline & $2+$ & $6(12.0)$ & $3(6.0)$ & $6(12.0)$ & $11(22.0)$ \\
\hline & $3+$ & $16(32.0)$ & $21(42.0)$ & $18(36.0)$ & $15(30.0)$ \\
\hline & $4+$ & $26(52.0)$ & $26(52.0)$ & $25(50.0)$ & $22(44.0)$ \\
\hline \multirow[t]{6}{*}{ 2nd (BGS-17-05) } & Number & 51 & 51 & 51 & 51 \\
\hline & Negative & - & $50(98.0)$ & $1(2.0)^{*}$ & - \\
\hline & $1+$ & $1(2.0)$ & - & $1(2.0)$ & - \\
\hline & $2+$ & $6(11.8)$ & - & $3(59)$ & $1(2.0)$ \\
\hline & $3+$ & $16(31.4)$ & - & $14(27.5)$ & $21(41.2)$ \\
\hline & $4+$ & $88(54.8)$ & $1(2.0)^{\star}$ & $32(62.7)$ & $29(56.9)$ \\
\hline
\end{tabular}

Values are presented as number (\%), unless otherwise stated.

${ }^{\star}$ Unacceptable responses for the Rh CcEe antigen test.

\section{3. 일반 수혈항체검사}

1) 비예기항체 선별검사

비예기항체 선별검사는 1 차와 2 차의 경우 모두 2 개의 양 성 검체와 1 개의 음성 검체를 발송하였다. 1 차 검체에서 2 개
의 항체 양성 검체에 대하여 각각 음성으로 보고한 1 개와 5 개 기관을 제외한 $98.6 \%$, 그리고 2차 검체에서는 모든 검체에서 $100.0 \%$ 의 정답률을 보였다(Table 7). 1차(2차) 검사법의 비 율은 원주응집법 93.8\% (94.5\%), erythrocyte-magnetized 
Journal of LABORATORY MEDICINE and QUALITY ASSURANCE

Young Ae Lim et al • Annual Report (2017) for Transfusion Medicine EQA

Table 6. Number (\%) of participants in the proficiency tests for weak D test

\begin{tabular}{|c|c|c|c|c|}
\hline \multirow{2}{*}{ Trial (specimen) } & \multicolumn{2}{|c|}{1 (BGS-17-03) } & \multicolumn{2}{|c|}{2 (BGS-17-06) } \\
\hline & RhD & Weak D & $\mathrm{RhD}$ & Weak D \\
\hline Number & 141 & 142 & 158 & 159 \\
\hline Negative & $34(24.1)$ & $3(2.1)^{\star}$ & $100(63.3)$ & - \\
\hline \pm & $15(10.6)$ & - & 33 (20.9) & - \\
\hline $1+$ & $39(27.7)$ & $6(4.2)$ & $18(11.4)$ & $8(5.0)$ \\
\hline $2+$ & $44(31.2)$ & $25(17.6)$ & $5(3.2)$ & $35(22.0)$ \\
\hline $3+$ & $7(5.0)$ & $39(27.5)$ & $1(0.6)$ & $46(28.9)$ \\
\hline $4+$ & $2(1.4)^{\star}$ & $55(38.7)$ & $1(0.6)^{\star}$ & $66(41.5)$ \\
\hline Not done & - & $14(9.9)$ & - & $4(2.5)$ \\
\hline D positive & \multicolumn{2}{|c|}{$68(47.6)$} & \multicolumn{2}{|c|}{$34(21.3)$} \\
\hline $\mathrm{D}$ variant & \multicolumn{2}{|c|}{$74(51.7)$} & \multicolumn{2}{|c|}{$126(78.7)$} \\
\hline $\mathrm{D}$ negative & \multicolumn{2}{|c|}{$1(0.7)^{*}$} & \multicolumn{2}{|c|}{ - } \\
\hline
\end{tabular}

Values are presented as number (\%), unless otherwise stated.

${ }^{\star}$ Unacceptable responses for weak D testing.

Table 7. Number (\%) of participants in the proficiency tests for antibody screening

\begin{tabular}{|c|c|c|c|c|c|}
\hline \multirow{2}{*}{ Trial } & \multirow{2}{*}{ Specimen } & \multirow{2}{*}{ Number } & \multicolumn{2}{|c|}{ Results } & \multirow{2}{*}{ Intended response } \\
\hline & & & Positive & Negative & \\
\hline \multirow[t]{3}{*}{1 st } & BBG-17-01 & 288 & $287(99.7)$ & $1(0.3)^{\star}$ & Positive \\
\hline & BBG-17-02 & 288 & $283(98.3)$ & $5(1.7)^{\star}$ & Positive \\
\hline & BBG-17-03 & 288 & $4(1.4)^{\star}$ & $284(98.6)$ & Negative \\
\hline \multirow[t]{3}{*}{$2 \mathrm{nd}$} & BBG-17-07 & 292 & - & $292(100.0)$ & Negative \\
\hline & BBG-17-08 & 292 & $292(100.0)$ & - & Positive \\
\hline & BBG-17-09 & 292 & $292(100.0)$ & - & Positive \\
\hline
\end{tabular}

Values are presented as number (\%), unless otherwise stated.

*Unacceptable responses for antibody screening.

technique $1.7 \%(2.4 \%)$, liquid microwell plate $0.7 \%$ (0.7\%), solid phase red cell adherence assay 3.5\% (2.1\%), 그리고 시험관법은 $3.5 \%$ (2.1\%)를 차지하였다.

\section{2) 직접항글로불린검사}

직접항글로불린검사는 2 차에 걸쳐 총 6 개의 검체가 사용되 었다. 다특이성 항글로불린검사는 한 개의 음성 검체에 대하여 위양성으로 보고한 2개 기관과 양성 검체에 대하여 위음성으 로 보고한 한 개의 기관을 제외한 4 개 검체 모두에서 $100.0 \%$ 의 정답률을 보였다. Immunoglobulin-G (IgG) 단특이성 항 글로불린검사는 6 개의 모든 검체에서 $100.0 \%$ 의 정답률을 보 였다. 그러나 C3d 단특이성 항글로불린검사의 경우 다특이성 항글로불린검사의 결과에 따라 결과가 달랐는데, 4 개의 다특 이성 항글로불린검사 음성 검체는 모두 $100.0 \%$ 의 정답률을
보인 반면, 다특이성 항글로불린검사 양성 검체에 대해서는 1 차는 $16.4 \%, 2$ 차는 $12.7 \%$ 의 위양성을 보였다(Table 8).

참가기관들은 원주응집법과 시험관법을 사용하고 있는데, 다특이성 항글로불린검사의 원주응집법과 시험관법의 $\%$ 는 1 차의 경우 $79.5 \%$ 와 $20.5 \%, 2$ 차의 경우 $80.3 \%$ 와 $19.7 \%$ 였다. 다특이성 항글로불린검사 양성 검체의 경우 $2+$ 이상의 응집 강도를 보인 기관들이 전체 참여기관 중 차지하는 백분율은 1 차 $95.6 \%, 2$ 차는 $91.8 \%$ 였다. 다특이성과 C3d 단특이성 항글 로불린검사에서 위양성을 보인 기관들의 혈구응집은 $1+$ 부터 $4+$ 까지 강한 응집을 보고한 기관들도 포함되어 있었다.

\section{4. 특수 수혈항체검사}

1) 비예기항체 동정검사

각 항체별 동정검사의 정답률은 anti-C $97.6 \%$, anti-S 


\section{Journal of LABORATORY MEDICINE and QUALITY ASSURANCE}

Young Ae Lim et al • Annual Report (2017) for Transfusion Medicine EQA

Table 8. Number (\%) of participants in the proficiency tests for the direct antiglobulin test

\begin{tabular}{|c|c|c|c|c|c|c|}
\hline \multirow{2}{*}{ Trial } & \multirow{2}{*}{ Antiglobulin } & \multirow{2}{*}{ Specimen } & \multirow{2}{*}{ Number } & \multicolumn{2}{|c|}{ Result } & \multirow{2}{*}{ Intended response } \\
\hline & & & & Positive & Negative & \\
\hline \multirow[t]{9}{*}{1 st } & Polyspecific & BBG-17-04 & 253 & & $253(100.0)$ & Negative \\
\hline & & BBG-17-05 & & & $253(100.0)$ & Negative \\
\hline & & BBG-17-06 & & $253(100.0)$ & 0 & Positive \\
\hline & Anti-IgG & BBG-17-04 & 67 & 0 & $67(100.0)$ & Negative \\
\hline & & BBG-17-05 & & 0 & $67(100.0)$ & Negative \\
\hline & & BBG-17-06 & & $67(100.0)$ & 0 & Positive \\
\hline & Anti-C3d & BBG-17-04 & 73 & 0 & $73(100.0)$ & Negative \\
\hline & & BBG-17-05 & & 0 & $73(100.0)$ & Negative \\
\hline & & BBG-17-06 & & $12(16.4)^{\star}$ & $61(83.6)$ & Negative \\
\hline \multirow[t]{9}{*}{ 2nd } & Polyspecific & BBG-17-10 & 258 & & $258(100.0)$ & Negative \\
\hline & & BBG-17-11 & & $2(0.8)^{\star}$ & $256(99.2)$ & Negative \\
\hline & & BBG-17-12 & & $257(99.6)$ & $1(0.4)^{*}$ & Positive \\
\hline & Anti-IgG & BBG-17-10 & 68 & & $68(100.0)$ & Negative \\
\hline & & BBG-17-11 & & & $68(100.0)$ & Negative \\
\hline & & BBG-17-12 & & $68(100.0)$ & & Positive \\
\hline & Anti-C3d & BBG-17-10 & 71 & & $71(100.0)$ & Negative \\
\hline & & BBG-17-11 & & & $71(100.0)$ & Negative \\
\hline & & BBG-17-12 & & $9(12.7)^{*}$ & $62(87.3)$ & Negative \\
\hline
\end{tabular}

Values are presented as number (\%), unless otherwise stated.

Abbreviation: IgG, immunoglobulin G.

${ }^{*}$ Unacceptable responses for direct antiglobulin test.

Table 9. Number (\%) of participants in the proficiency tests for antibody identification

\begin{tabular}{cccccl}
\hline \multirow{2}{*}{ Trial } & \multirow{2}{*}{ Specimen } & \multirow{2}{*}{ Number } & \multicolumn{2}{c}{ Intended response } & \\
\cline { 4 - 5 } & & & Ab & No. (\%) & \multirow{2}{*}{ Other responses (no. of participants) } \\
\hline 1 & BBS-17-01 & 123 & Anti-C & $120(97.6)$ & Anti-C\&S (2), anti-E (1) \\
\cline { 5 - 6 } 2 & BBS-17-02 & 123 & Anti-S & $121(98.4)$ & Not done (2) \\
& BBS-17-04 & 123 & Anti-c & $109(88.7)$ & Anti-c+anti-E (11), anti-Jk+anti-c (1), not done (2) \\
\hline
\end{tabular}

98.4\%, anti-Jk ${ }^{\mathrm{b}} 99.2 \%$ 로 우수하였으나, anti-c는 $88.7 \%$ 의 정답률을 보였다(Table 9). 또한 매 회차 시 2 개 검체의 답변 을 한 개 검체에 표시하고 나머지 검체에는 'not done'을 표시 한 기관이 1 차 2 기관, 2 차에는 1 기관의 총 3 기관으로 이들의 결과는 오답으로 처리하였다.

\section{2) $\mathrm{ABO}$ 항체 역가검사}

각 방법별 $\mathrm{ABO}$ 항체 역가검사결과는 Table 10 과 같으며 허 용범위는 굵은 글씨로 표시하였다. Anti-A의 경우 허용범위에 드는 참여기관 비율은 1 차와 2 차는 각각 시험관 즉시원침법
은 모두 $95.2 \%$ 와 $88.1 \%$, 시험관 실온배양법은 모두 $100.0 \%$, 시험관 항글로불린법 $100.0 \%$ 와 $94.1 \%$, 원주응집 실온법 $100.0 \%$ 와 $84.6 \%$, 원주응집 항글로불린법은 모두 $96.0 \%$ 였 다. Anti-B의 경우 허용범위에 드는 참여기관 비율은 1 차와 2 차는 각각 시험관 즉시원침법은 모두 $97.6 \%$ 와 $92.9 \%$, 시험관 실온배양법은 모두 $100.0 \%$, 시험관 항글로불린법 $93.8 \%$ 와 $94.1 \%$, 원주응집 실온법 $100.0 \%$ 와 $92.3 \%$, 원주응집 항글로 불린법은 모두 $100.0 \%$ 였다(Table 10). 검사법은 시험관 즉시 원침법을 사용하는 기관이 42 기관으로 가장 많았으며, 원주응 집 항글로불린법 25 기관, 시험관 실온배양법과 시험관 항글로 
Journal of LABORATORY MEDICINE and QUALITY ASSURANCE

Young Ae Lim et al • Annual Report (2017) for Transfusion Medicine EQA

Table 10. Number of participants involved in each of the techniques for $A B O$ antibody titration

\begin{tabular}{|c|c|c|c|c|c|c|c|c|c|c|c|}
\hline \multirow{2}{*}{ Technique } & \multirow{2}{*}{ Trial } & \multirow{2}{*}{ Number } & \multirow{2}{*}{$\begin{array}{c}\text { Acceptable } \\
\text { range (\%) }\end{array}$} & \multicolumn{8}{|c|}{ Titer } \\
\hline & & & & 2 & 4 & 8 & 16 & 32 & 64 & 128 & 256 \\
\hline \multicolumn{12}{|l|}{ Anti-A } \\
\hline Tube-IS & 1 & 42 & 95.2 & & 2 & 6 & 22 & 12 & & & \\
\hline Tube-RT & & 16 & 100.0 & & & & 11 & 5 & & & \\
\hline Tube-AHG & & 16 & 100.0 & & & & 2 & 6 & 8 & & \\
\hline Tube-AHG, DTT & & 5 & & & & 2 & 1 & 1 & 1 & & \\
\hline CAT-RT & & 12 & 100.0 & & & 3 & 9 & & & & \\
\hline CAT-AHG & & 25 & 96.0 & & & & 6 & 12 & 6 & 1 & \\
\hline CAT-AHG, DTT & & 6 & & & & & 1 & 1 & 4 & & \\
\hline Others & & 1 & & & & 1 & & & & & \\
\hline Total & & 123 & & 0 & 2 & 12 & 52 & 37 & 19 & 1 & 0 \\
\hline Tube-IS & 2 & 42 & 88.1 & & & 3 & 18 & 16 & 3 & 2 & \\
\hline Tube-RT & & 17 & 100.0 & & & & 1 & 13 & 3 & & \\
\hline Tube-AHG & & 17 & 94.1 & & & & 1 & 2 & 9 & 5 & \\
\hline Tube-AHG, DTT & & 5 & & & & 1 & 3 & & 1 & & \\
\hline CAT-RT & & 13 & 84.6 & & & 2 & 5 & 6 & & & \\
\hline CAT-AHG & & 25 & 96.0 & & & & & & 13 & 11 & 1 \\
\hline CAT-AHG, DTT & & 6 & & & & & & 1 & 3 & 1 & 1 \\
\hline CAT-AHG, DTT & & 1 & & & & & & 1 & & & \\
\hline Total & & 126 & & 0 & 0 & 6 & 28 & 39 & 32 & 19 & 2 \\
\hline \multicolumn{12}{|l|}{ Anti-B } \\
\hline Tube-IS & 1 & 42 & 97.6 & & & 1 & 11 & 24 & 6 & & \\
\hline Tube-RT & & 16 & 100.0 & & & & 1 & 10 & 5 & & \\
\hline Tube-AHG & & 16 & 93.8 & & & & 1 & 4 & 9 & 2 & \\
\hline Tube-AHG, DTT & & 5 & & & 1 & 2 & 1 & & 1 & & \\
\hline CAT-RT & & 12 & 100.0 & & & & 7 & 5 & & & \\
\hline CAT-AHG & & 25 & 100.0 & & & & 9 & 12 & 4 & & \\
\hline CAT-AHG, DTT & & 6 & & & 2 & & & 2 & 2 & & \\
\hline Others & & 1 & & & & & 1 & & & & \\
\hline Total & & 123 & & 0 & 3 & 3 & 31 & 57 & 27 & 2 & 0 \\
\hline Tube-IS & 2 & 42 & 92.9 & 1 & 7 & 13 & 16 & 3 & 1 & 1 & \\
\hline Tube-RT & & 17 & 100.0 & & & 8 & 5 & 4 & & & \\
\hline Tube-AHG & & 17 & 94.1 & & & & 1 & 2 & 10 & 4 & \\
\hline Tube-AHG, DTT & & 5 & & & & & 3 & 1 & 1 & & \\
\hline CAT-RT & & 13 & 92.3 & 1 & 4 & 8 & & & & & \\
\hline CAT-AHG & & 25 & 100.0 & & & & 5 & 13 & 7 & & \\
\hline CAT-AHG, DTT & & 6 & & & & 1 & 1 & 2 & 2 & & \\
\hline Others & & 1 & & & & & 1 & & & & \\
\hline Total & & 126 & & 2 & 11 & 30 & 32 & 25 & 21 & 5 & 0 \\
\hline
\end{tabular}

The bold text indicates acceptable range.

Abbreviations: IS, immediate spin; RT, room temperature incubation; AHG, indirect anti-human globulin test; DTT, dithiothreitol; CAT, column agglutination technology. 
Journal of LABORATORY MEDICINE and QUALITY ASSURANCE

Young Ae Lim et al • Annual Report (2017) for Transfusion Medicine EQA

불린법이 각각 17 기관, 원주응집 실온법 13 기관 순으로 나타 났다.

\section{5. 워크숍 개최}

수혈 전 검사 실기 워크솝을 2017년 8월 26일(금) 오전 9시 부터 17시까지 아주대학교 의과대학 송재관학생실습실에서 1 회만 개최하였다. 내용은 $\mathrm{ABO}$ 아형, $\mathrm{RhD}$ 변이형 검체검사 검출법, 비예기항체 검출원리, 비예기항체 선별과 동정에 대하 여 실시하였다. 오전에는 이론강의를 실시하였는데 68 명이 참 석하였고, 오후에는 실습이 이루어졌으며 50명이 참석하였다.

\section{고찰}

검사건수는 2016년도에 비하여 2017년도에 많이 증가하였 는데, 특히 일반수혈검사와 특수 수혈항원검사의 약 $\mathrm{D}$ 검사의 참여기관 수가 많이 증가하였고 1차에 비하여 2차에 더욱 참 가기관 수가 증가하였다. 이는 2017년 7월부터 건강보험 등에 '검체검사 질가산' 제도가 신설됨에 따른 영향으로 여겨진다.

2016년까지는 혈구용 검체로 희석된 혈구부유액과 혈청형 검체로 혈장을 별도로 분리하여 발송하였으나 이는 환자로부 터 유래된 전혈을 이용하여 혈액형검사를 실시하여야 하는 실 제 검사실의 현황을 반영하지 못하고 최근 증가하는 자동화 장 비에 검체를 장착할 수 없다는 단점이 있었다. 따라서 이를 보 완하고자 2017년부터는 실제 검사실 환경을 반영하게끔 정도 관리용 검체를 $20 \%$ 의 재조합 전혈이 되도록 농축적혈구와 동 형의 신선동결혈장과 세포보존액으로 희석하여 제조하였다. 그럼에도 불구하고 일부의 자동화 장비에서는 검사가 불가능 하였는데 이 경우에는 검체를 농축하거나 수기법으로 시행하 는 것을 권장하며, 특정 제조사의 자동화 장비를 위한 별도의 검체 제공도 고려할 필요가 있겠다.

혈구응집 정도는 적혈구 항원과 항체반응의 간접지표이며 항원 정도 혹은 항체 역가를 예측하는 데 도움을 줄 수 있으므 로 단순히 응집과 비응집으로 표시하는 것보다는 혈구응집 정 도를 음성,, $\pm 1+, 2+, 3+, 4+$ 의 6 단계로 구분하여 표시 하는 것이 중요하다[3]. 2017년도 최종보고서가 지연되어 참 여기관들에게 피드백의 기회가 없었다는 점 때문에 2017년도 에 한하여 일반수혈검사의 $\mathrm{ABO}$ 혈액형, $\mathrm{RhD}$ 혈액형과 교차 시험의 경우 혈구응집 강도에 대하여 모두 code 507 로 시범항 목으로 간주하여 평가에서 제외하였고, $\mathrm{ABO}$ 혈액형검사에서 혈구형이나 혈청만을 실시한 기관에 대해서도 시범항목으로 간주하여 부적합으로 평가하지는 않았다.

혈구응집 정도는 항원과 항체반응의 간접지표이므로 적혈구
항원 정도를 가름하여 $\mathrm{ABO}$ 혹은 $\mathrm{D}$ 혈액형의 아형을 검출하 거나 $\mathrm{ABO}$ 항체 역가의 감소를 예측하는 데 도움을 줄 수 있으 므로 정확한 혈액형을 판정하거나 환자의 임상상황을 판단하 는 데 도움을 줄 수 있다. 따라서 동일 검체에 대하여 타 기관 과의 혈구응집 정도의 비교는 검사법 수기와 판독의 정확성을 검증할 수 있는 유익한 정보로 간주할 수 있다. 따라서 2018년 부터 이러한 경우는 모두 부적합으로 간주할 예정이므로 $\mathrm{ABO}$ 와 $\mathrm{RhD}$ 혈액형검사의 경우 응집 정도를 반드시 선택할 필요 가 있겠다.

혈구형이나 혈청형의 단독으로 혈액형 판정을 할 경우에는 혈액형 판정이 정확하지 않을 수 있으나 이를 인지할 수 없는 경우가 있으므로 반드시 혈구형과 혈청형을 모두 실시하여야 $\mathrm{ABO}$ 혈액형 판정이 가능하다[3]. 즉 혈구형과 혈청형검사는 $\mathrm{ABO}$ 혈액형검사과정 중 두 단계를 의미하므로 이 두 단계를 모두 시행하여야만 검사를 혈액형검사를 완벽히 시행한 것이 며, 선택할 수 있는 $\mathrm{ABO}$ 혈액형검사법의 종류가 아니라는 점 을 검사기관들이 명심할 필요가 있겠다. 따라서 혈청형에 필요 한 물품들이 구비되어 있지 않고 이를 시행하지 않는 검사실 이라면 $\mathrm{ABO}$ 혈액형검사를 정확하게 검사하고 있는 검사실이 라고 보기가 어렵다. 그럼에도 불구하고 2017년도 1차와 2차 의 경우 혈청형검사를 실시하지 않은 기관의 비율이 $4.7 \%$ 와 $5.5 \%$ 를 차지하였다(자료 제시하지 않음). 보건복지부 고시 제 2015-145호(2015년 8월 18일)에서도 건강보험 행위급여의 수 혈검사 중 '나-201 ABO 혈액형검사는 혈구형검사와 혈청형 검사를 모두 시행한 경우에만 산정한다.'라고 명시되어 있듯이 $\mathrm{ABO}$ 혈액형검사법에 대한 혈구형검사와 혈청형검사의 중요 성을 강조할 필요가 있겠다.

비록 2017년 평가에는 $\mathrm{ABO}$ 혈액형검사의 경우 혈구형검사 만 실시하고 혈청형검사를 실시하지 않은 경우 피드백 기회가 없었고 협회의 전산작업의 추가작업이 필요하여 부적합으로 평가하지 않았으나 2018년부터 이러한 경우는 설명문에 확실 히 안내하고 전산작업을 완료하여 모두 부적합으로 간주할 예 정이므로 이에 대한 사항은 설명문에 강조하고, 참여기관들은 검사 전 설명문을 자세히 검토할 필요가 있겠다.

발송하는 검체 중 부적합 교차시험 검체는 항글로불린단 계에서 대략 2 에서 $3+$ 응집이 되도록 제조한 검체이므로 항 글로불린이 첨가되지 않은 시험관 $37^{\circ} \mathrm{C}$ low-ionic-strength solution (LISS)법, 시험관 $37^{\circ} \mathrm{C}$ PEG (polyethylene glycol) 법, 시험관 $37^{\circ} \mathrm{C}$ 알부민법, 시험관 LISS법과 시험관 식염수법 에서는 $2+$ 이상의 응집을 나타내기 어려웠음에도 불구하고 이 정도 혹은 이상의 응집을 보고한 기관들이 있었다. 이에 따 라 교차시험 적합 검체를 부적합으로 판정한 기관이 검체에 따 


\section{Journal of LABORATORY MEDICINE and QUALITY ASSURANCE}

\section{Young Ae Lim et al • Annual Report (2017) for Transfusion Medicine EQA}

라 전체기관의 $1.5 \%-2.4 \%$ 를 차지하였다. 따라서 이러한 기 관들은 검사를 민감하게 시행하였다기보다는 실제 환자의 검 체에 대하여 위양성을 보고할 가능성이 많으므로 교차검사법 을 점검할 필요가 있겠다. 이와는 반대로 부적합 검체를 반드 시 검출할 수 있어야 하는 항글로불린단계를 사용함에도 불구 하고 위음성을 보인 기관들도 있었는데, 교차시험 부적합 검체 를 적합으로 판정한 기관이 검체에 따라 전체기관의 $11.1 \%$ 와 $9.6 \%$ 를 차지하여 수혈현장에서 환자에게 심각한 위해를 줄 가능성도 있으므로 이들 기관에 대한 올바른 검사법 교육이 절 실한 것으로 여겨졌다. 최근 의료기관에서 교차시험을 실시한 혈액을 수혈받았음에도 불구하고 항-E, 항-c, 항- $\mathrm{Jk}^{\mathrm{b}}$ 복합 비 예기항체에 의한 급성 용혈수혈반응 1 예의 보고에서는 비예기 항체에 의한 수혈부작용을 예방하기 위해서는 항글로불린단 계를 포함한 비예기항체 검출검사가 필수적으로 시행되어야 하며 실시기관에서의 더욱 엄격한 정도관리의 필요성을 강조 하였다[4].

정상 $\mathrm{ABO}$ 혈액형은 일반적으로 시험관법 혈구형과 혈청형 에서 $3+$ 이상의 응집을 보이기는 하나 $3+$ 이상의 응집을 보 인다고 해서 무조건 정상 $\mathrm{ABO}$ 혈액형으로 간주하는 것은 옳 지 못하다[5]. $\mathrm{A}_{2} \mathrm{Bw}$ 검체에 대하여 $\mathrm{B}$ 항에 $3+$ 이상을 보였 던 16 개 기관 중 9 개 기관에서 정상 $\mathrm{B}$ 형 항원으로 판정하였다. 따라서 검사기관 혹은 검사법에 따라 정상 $\mathrm{ABO}$ 혈액형에 대 한 응집 범위가 달라질 수 있으므로 각 검사실에서 정상인을 대상으로 $\mathrm{ABO}$ 혈액형의 경우 혈구형과 혈청형검사에서 보일 수 있는 혈구응집 범위를 파악하여 이 범위를 벗어날 경우의 재검토 범위를 재산정할 필요가 있겠다.

2017년에 1차와 2차에 보낸 약 D검사 검체는 모두 D 혈액 형검사에서도 정상 $\mathrm{Rh}$ 양성에 비해서는 약하지만 응집을 보 인 변이형 $\mathrm{D}$ 검체였다. 일반적으로 정상 $\mathrm{D}$ 양성 혈액형의 경 우 시험관법에서 $3+$ 이상의 응집을 보이는 반면, 변이형 $\mathrm{D}$ 형은 $2+$ 이하의 응집을 보이는 것으로 되어 있다[5]. 따라서 $\mathrm{D}$ 혈액형검사에서 $2+$ 이하의 응집을 보이는 경우에는 무조 건 $\mathrm{D}$ 양성 혈액형이라고 판정하기보다는 응집이 정상 $\mathrm{D}$ 양성 에 비하여 미약하였으므로 반드시 D 변이형을 의심하거나 다 른 시약으로 재검할 수 있어야 한다. 2017년 외부신빙도조사 에서는 $3+$ 이상의 응집을 보고한 기관들이 1 차 $66.2 \%, 2$ 차 $70.4 \%$ 에서 보고하였으며 D 양성으로 보고한 기관들도 $47.6 \%$ 와 $21.3 \%$ 에 달하였다. 2017년도에는 1차 보고서 발송이 늦어 져 참여기관들에게 피드백할 기회가 없어서 $\mathrm{D}$ 양성 혈액형이 라고 판정한 상당수의 기관에 대해서도 2017년에는 시범적으 로 ‘acceptable’로 평가하였으나, 2018년부터 비록 80\%를 넘 지 않더라도 D 변이형으로 규명된 검체에 한해서는 D 변이형
만을 정답으로 간주할 예정이다.

2017년부터는 직접항글로불린검사의 보고서 방식을 검체 번호 중심에서 다특이성, 항-IgG 단특이성, 항-C3d 단특이성 검사법 중심으로 바꾸어 보고하게 되었다. IgG가 감작된 적혈 구 검체의 경우에 다특이성과 항- $\operatorname{IgG}$ 단특이성만 양성으로 보 고하여야 함에도 불구하고 1 차 $16.4 \%, 2$ 차 $12.7 \%$ 의 기관에 서 항-C3d 단특이성까지 양성으로 보고하고 있다. 만약 검사 를 하기 전에 이미 혈구응집이 있는 경우에는 모두 양성을 보 일 수 있으므로 반드시 이런 경우 항글로불린을 첨가하지 않 는 음성 대조군과 함께 시행하여 혈구응집 여부를 배제할 필 요가 있다. 또한 이러한 기관들은 음성인 검체에 대해서는 모 두 음성으로 보고하는 것으로 보아 검사 수기를 잘못하였다기 보다는 항- $\operatorname{IgG}$ 단특이성과 항-C3d 단특이성 시약이 혼합되어 있는 다특이성 시약에 양성을 보인 것을 항-IgG 단특이성과 항-C3d 단특이성 시약 각각에 양성으로 잘못 보고하였을 가능 성도 있으므로 이에 대한 정확한 판정 해석에 대한 교육이 필 요한 것으로 보여진다.

2017년 비예기항체 동정검사의 검체는 anti-C, anti-S, anti-c 그리고 anti-Jk ${ }^{\mathrm{b}}$ 로 구성하였는데 이 중 anti-c의 경우 정답률이 $88.7 \%$ 에 지나지 않았다. Anti-c의 경우 anti-c 이외 에도 anti-E까지 같이 복합항체로 보고한 기관이 11 기관으로 $9 \%$ 에 달하는데, 이는 상품화된 항체 동정용 혈구의 항원구성 이 $\mathrm{E}$ 항원은 모두 c항원과 같이 표현되어 있기 때문에 응집반 응이 없는 적혈구가 가진 항원을 배제하는 exclusion법(rule out)을 사용하게 될 때 $\mathrm{E}$ 항원에 대한 항체를 배제하기가 쉽지 않기 때문이다. 또한 환자 적혈구에서 항원 표현형검사를 실시 하는 것이 도움이 되긴 하나 정도관리물질인 경우에는 환자의 적혈구가 제공되지 않으므로 항원 표현형검사를 실시할 수 없 다. 일반적으로 복합항체는 단일항체에 비하여 혈구응집이 강 하여 동형접합체 항원을 가진 적혈구는 이형접합체 항원을 가 진 적혈구에 비하여 해당 항체와의 반응이 더 강하다는 용량 효과(dosage effect)를 항체동정 시에는 반드시 고려할 필요가 있다. 2 차 검체의 anti-c의 경우 $\mathrm{E}$ 항원과 $c$ 항원이 표현된 적혈 구들의 응집 강도가 c항원만 표현된 적혈구에 비하여 강하지 않고 동일하였으므로 복합항체의 가능성을 배제되었어야 한 다. 2014년 2차 검체의 anti-C와 anti-e 경우는 반대로 용량 효과를 고려하지 않아 anti-e만 보고한 기관도 있어 정답률이 $69.8 \%$ 에 지나지 않았다[6]. 따라서 비예기항체 동정 시에는 용량효과로 인하여 혈구응집의 강도가 다르게 나타나는 것을 잘 관찰할 필요가 있다.

차세대 신빙도조사사업을 처음으로 시행한 2017년도 4개의 수혈의학프로그램의 10 가지 종목을 시행하였고 이에 대한 결 


\section{Journal of LABORATORY MEDICINE and QUALITY ASSURANCE}

Young Ae Lim et al • Annual Report (2017) for Transfusion Medicine EQA

과를 분석하여 발송하였기에 참여기관들의 검사실 향상에 도 움을 주었을 것으로 평가할 수 있었다.

\section{REFERENCES}

1. Lim YA, Cho HS. Annual report on the external quality assessment scheme for immunohematology testing in Korea (2016). J Lab Med Qual Assur 2017;39:107-16.

2. Lim YA, Cho HS, Kwon SW, Kwon KC, Kim SY, Park KU, et al. Annual report on the external quality assessment scheme for blood bank tests in Korea (2015). J Lab Med Qual Assur 2016;38:59-67.

3. Roback JD; American Association of Blood Banks. Technical manual. 17th ed. Bethesda (MD): American Asso- ciation of Blood Banks, 2011.

4. An GD, Kim KH, Jeong IH, Lim HH, Woo KS, Han JY, et al. Revisiting the pre-transfusion test: a case of acute hemolytic transfusion reaction due to multiple alloantibodies of anti-E, anti-c, anti-Jk(b). Korean J Blood Transfus 2017;28:170-6.

5. Lim YA, Cho HS, Choi YS, Jang CH, Lee MN, Kwon JR, et al. Report on external proficiency testing for the $\mathrm{ABO}$ and D blood group typing tests in blood centers (2015). Korean J Blood Transfus 2016;27:68-78.

6. Lim YA, Oh JS, Kwon SW, Kwon KC, Kim SY, Park KU, et al. Annual report on the external quality assessment scheme for blood blank tests in Korea (2014). J Lab Med Qual Assur 2015;37:47-55. 
${ }^{1}$ 아주대학교 의과대학 진단검사의학교실, ${ }^{2}$ 아주대학교병원 진단검사의학과

2017년에 시행된 수혈의학프로그램 검사에 대한 신빙도조사결과를 보고하고자 한다. 검체는 아 주대학교병원에서 직접 제조하여 참여기관들에게 연 2회 발송하였다. 10 개의 평가종목에 대한 정 답률은(평균 참여기관 수) 다음과 같았다. $\mathrm{ABO}$ 혈액형검사 $99.1 \%-99.9 \%$ (714), RhD 혈액형검 사 99.3\%-100.0\% (695), 교차시험검사 88.9\%-98.5\% (618), ABO 아형 혈액형 80.7\%와 96.0\% (51), Rh CcEe 항원검사 98.8\%-100.0\% (51), 약 D검사 99.3\%와 100.0\% (150), 비예기항체 선별 검사 98.6\%-100.0\% (295), 직접항글로불린검사는 다특이성 99.2\%-100.0\% (256), 단특이성 $\operatorname{lgG}$

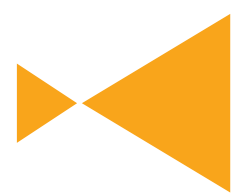

Journal of

LABORATORY MEDICINE and

QUALITY ASSURANCE 모두100.0\% (68), 그리고 단특이성 C3d 83.6\%-100.0\% (72), 비예기항체 동정검사 88.7\%-99.2\% (123), 그리고 ABO 항체 역가검사 84.6\%-100.0\% (73)이었다. 2017년 수혈의학프로그램 신빙도 조사에 참여한 기관 수는 2016년에 비하여 많이 증가하였다. $\mathrm{ABO}$ 아형 혈액형검사를 제외하고 2017년도 수혈의학프로그램 검사의 신빙도결과는 2016년도에 비하여 우수한 편이었으며, 참여 검 사실의 질 향상에 기여하였다.

(J Lab Med Qual Assur 2018;40:9-20)

교신저자: 임영애

우)16499 경기도 수원시 영통구 월드컵로 164, 아주대학교 의과대학 아주대학교병원 진단검사의학교실 Tel: 031)219-5786, Fax: 031)219-5778, E-mail: limyoung@ajou.ac.kr 